\title{
PLC Tabanlı Uygulamalar: Mill Makinelerinde Oluşacak İş Kazalarının PLC Kullanılarak Önlenmesi
}

\author{
Mehmet Ali Öner ${ }^{1}$, Serdar Solak ${ }^{2 *}$ \\ ${ }^{1}$ Kocaeli Üniversitesi, Teknoloji Fakültesi, Bilişim Sistemleri Mühendisliği Bölümü, Kocaeli, Türkiye (ORCID: 0000-0003-1918-6645), onermehmetali@gmail.com \\ ${ }^{2}$ Kocaeli Üniversitesi, Teknoloji Fakültesi, Bilişim Sistemleri Mühendisliği Bölümü, Kocaeli, Türkiye (ORCID: 0000-0003-1081-1598), serdars@kocaeli.edu.tr
}

(İlk Geliş Tarihi 18 Haziran 2020 ve Kabul Tarihi 8 Ekim 2020)

(DOI: 10.31590 /ejosat.754688)

ATIF/REFERENCE: Öner, M.A. \& Solak S. (2020). PLC Tabanlı Uygulamalar: Mill Makinelerinde Oluşacak İş Kazalarının PLC Kullanılarak Önlenmesi. Avrupa Bilim ve Teknoloji Dergisi, (20), 101-110.

$\ddot{O} z$

Günümüzde otomasyon sistemlerinin kullanımı giderek artmakta ve bu otomasyon sistemlerinin temelini genellikle Programlanabilir Lojik Kontrolör (PLC) tabanlı uygulamalar oluşturmaktadır. PLC, pek çok gelişmiş makine ve cihazın bulunduğu endüstride otomasyon amaçlı kullanılmaktadır. Endüstriyel otomasyon sistemlerinde PLC ile beraber kullanılan, merkezi denetim ve veri toplama (Supervisory Control and Data Acquisition SCADA), insan makine arayüzü (Human- Machine Interface HMI) sistemleri, insan hatalarını ve müdahalesini en aza indirgeyerek güvenli, kaliteli ve hızlı üretim yapmasını sağlamaktadır. Endüstriler de kullanılan bu sistemler sayesinde, geliştirilen otomasyon yazılımları 7/24 çalışarak yüksek kalite ve düşük maliyetli seri üretime olanak tanımaktadır. Büyük işletmeler insan gücünü ve hatasını en aza indirmek, iş kazalarını önlemek, maliyeti düşürmek, kaliteli ve hızlı üretim yapmak amacıyla otomasyon sistemleri kullanmayı tercih etmektedirler. PLC'ler özellikle gıda, kimya lastik, otomotiv sektörlerinde ambalajlama paketleme sistemlerinde, çimento fabrikalarında, havalandırma ve soğutma tesislerinde, tekstil fabrikalarında yaygın olarak kullanılmaktadır. Endüstrilerde yaygın olarak kullanılan bu sistemler, basit programlama yapısı, kurulum, kullanım ve montaj kolaylığı, zor çalışma ortamlarında dayanıklı bir şekilde çalışması, fazla arıza çıkarmaması, az bakım istemesi ve enerji tüketimlerinin düşük olması sebebiyle tercih edilmektedirler. Makale çalışmasında, PLC tabanlı otomasyon sistemleri incelenerek uygulandığı alanlar ele alınmıştır. Ayrıca kamyon lastik üretim fabrikasında yer alan Mill makinalarının çalışması PLC ve HMI kullanılarak güvenli hale getiren örnek bir çalışma sunulmaktadır. Bu makinelere, güvenliğgi otomatik olarak sağlamak amacıyla giriş ve çıkış kartları eklenmiştir. Gerçekleştirilen bu çalışma sonucunda üretimin hızlı ve kaliteli yapılarak çalışanların iş kazasına uğrama riskinin azaltılması sağlanmıştır. Bunun yanı sıra geliştirilen HMI arayüz sayesinde ek bir bakımcı personele ihtiyaç duymadan makinalardaki arızanın ve güvenlik durumlarının kontrol ve takibi gerçekleştirilebilmektedir.

Anahtar Kelimeler: PLC, HMI, SCADA, İş güvenliği. Otomasyon.

\section{PLC Based Applications: Prevention of Work Accidents to Occur on Mill Machines Using PLC}

\begin{abstract}
In recent years, the use of automation systems has been increasing, and the basis of these automation systems is generally Programmable Logic Controller (PLC) based application. PLC is used for automation in the industry where there are many advanced machines and devices. In industrial automation systems, it is also used Supervisory Control and Data Acquisition (SCADA), Human - Machine Interface (HMI) systems to ensure safe, quality, and fast production by minimizing human errors and intervention. Because of these systems used in the industries, the automation software developed enables 24/7 production with high quality and low cost. Large-scale companies prefer to use automation systems in order to minimize worker labor and error, prevent work accidents, reduce costs, and make high quality and fast production. PLCs are widely used in packaging systems, especially in the food, chemical, tire, automotive industries, as well as in cement plants, ventilation and cooling facilities, and textile factories. These systems, which are widely used in industries, are preferred due to simple programming structure, ease of setup, use and assembly, durable operation in difficult working
\end{abstract}

\footnotetext{
* Sorumlu Yazar: Kocaeli Üniversitesi, Teknoloji Fakültesi, Bilişim Sistemleri Mühendisliği, Kocaeli, Türkiye ORCID: 0000-0003-1081-1598, serdars@kocaeli.edu.tr
} 
environments, low failure, low maintenance cost, and low energy consumption. This article presents the usage and application areas of PLC based automation systems. In addition, a case study is presented that Mill machines, commonly found in truck tire manufacturing factories, are secured using PLC and HMI. Input and output cards have been added to these machines to provide security automatically. As a result of the case study, the production is made faster and with higher quality, and employees are provided with a safer environment. In addition, thanks to the developed HMI interface, Mill machines are able to control and monitor malfunctions and safety situations without the need for additional maintenance personnel.

Keywords: PLC, HMI, SCADA, Safety, Automation systems.

\section{Giriş}

Eskiden otomasyon sistemlerinin kontrolü genellikle insanların kontrolünde elle veya otomatik kumanda elemanlarıyla yapılıyordu. Kontrolün bu şekilde yapılması çeşitli hataların oluşmasına, zaman ve enerji kaybına sebep olmaktadır. Günümüzde bu insan kaynaklarından oluşan etkileri azaltmak amacıyla, teknoloji ve bilimde yaşanan gelişmelerinde desteğiyle yeni otomasyon sistemleri geliştirilmiştir. İşletmelerde ve sanayi sektörlerinde üretimden yönetime kadar olan her yerde insan faktörü olmadan tamamen otomatik veya yarı otomatik olan üretim sürecine otomasyon denilmektedir. Endüstriyel otomasyon sistemlerinin etkinliğini arttırmak amaciyla, Programlanabilir Lojik Kontrolör (PLC) (Kaloyan, 2018), merkezi denetim ve veri toplama (Supervisory Control and Data Acquisition SCADA) ve insan makine arayüzü (Human- Machine Interface HMI) yaygın olarak kullanılmaktadır. $\mathrm{Bu}$ sistemler insan hatalarını ve müdahalesini en aza indirgeyerek, güvenli ve kaliteli üretim yapmasını sağlar. İnsan nüfusunun artmasıyla doğru orantılı olarak ihtiyaçlarda meydana gelen artış sonucunda, tüketim ve üretimde artmaktadır. Üretimde hızlı bir şekilde verimliliği ve kaliteyi arttırmak için işletmeler otomasyon sistemlerine ihtiyaç duymaktadır. Otomasyonlu üretim sistemleri teknolojinin de ilerlemesiyle sanayi sektörünün vazgeçilmezleri arasına girmektedir. Endüstriyel otomasyon sistemleri elektrik, elektronik, mekanik, hidrolik, pinomatik sistemlerini barındırmakta olup hız, sıcaklık, basınç ve sinyal dönüştürücü sistemlerini de kullanmaktadır (Bolton, 2015). Endüstrilerde otomasyon sistemleri $7 / 24$ çalışarak yüksek kalite ve düşük maliyetli seri üretime olanak tanımaktadır. Büyük işletmeler otomasyon sistemleri, insan gücünü en aza indirmek, maliyeti düşürmek, iş kazalarını azaltmak, kaliteyi arttırmak ve hızlı üretim yapmak sebebiyle tercih etmektedirler. Otomasyon sistemleri insan gücü ile yapılması zor veya imkânsız olan ürünleri icra etme özelliğine sahiptir. Otomasyon, Gerovitch' in ifade ettiği şekliyle " Bir üretim sürecinin, bir akış diyagramının veya bu durumda ki materyallerin insansız kontrol ve otonom şekle dönüşmesidir." tanımlanabilir (Salihoğlu, 2012). Otomasyon sistemleri teknolojinin gelişmesiyle birlikte üretimden ziyade işletmelerin tüm elemanlarının kontrolünü, analizini ve denetimini yüklenmişlerdir. PLC sistemleri otomasyon sistemlerinde en çok tercih edilen uygulamalardır.

PLC'ler 1968 yılında, röle kullanılarak yapılan kontrol siste mlerinin pahalı ve bakımlarının zor olması sebebiyle icat edilmiş tir. PLC fikri ilk olarak otomotiv şirketi olan GM'de çalışan Bill Stone tarafından Westinghouse isimli seminerde ortaya koymuştu r. Normal bir kontrol sistemlerinde yüzlerce ve binlerce röleler $b$ ulunmakta ve çok büyük alanlar kaplamaktaydı. Eskiden kullanıl an röleli kumanda sistemlerinin en büyük sorunlardan birisi, siste mde arıza oluştuğunda yüzlerce röle içinde arızanın bulunma zor luğu ve zaman almasıydı. Bu işlem uzun süreli üretim, iş ve eme k kayıplarına sebebiyet vermekteydi. Fazla maddi kayıplara uğra yan otomotiv firmaları daha az arıza yapan güvenilir dayanıklı ve hızlı PLC'li kumanda devrelerini geliştirmişlerdir (Erdinç, 2019)

PLC'ler genellikle gıda, kimya lastik, otomotiv sektörlerinde ambalajlama paketleme sistemlerinde, çimento fabrikalarında, havalandırma ve soğutma tesislerinde, tekstil fabrikalarında yaygın olarak kullanılmaktadır (Altın, 2011). Endüstride kullanılan kumanda kontrol sistemlerine göre PLC'ler çok fazla avantaja sahiptir. Bunları sıralamak gerekirse (MEGEB, 2011);

- Diğer sistemlere göre PLC'lerin programlanması daha kolaydır.

- Hataların giderilmesi diğerlerine göre PLC programında daha basittir.

- Eski kumanda sistemlerinde çözülemeyen problemeler PLC'ler tarafından çok kısa zamanda çözülebilir.

- Endüstrideki zor ortam koşullarında çalışmaya göre tasarlanmıştır.

- Otomasyon sistemlerine montajı gayet kolaydır.

- Eski kumanda sistemlerine nazaran gayet dayanıklı sağlam ve uzun ömürlüdürler.

- $\quad$ PLC'lerin üzerinde gelen mevcut I/O modüllerine ek olarak başka modüllerde eklenebilir.

- PLC'ler mevcut haberleşme modülleriyle kendileri veya başka ürünlerle de haberleşebilirler.

- $\quad$ PLC'ler çok hızlı çalışan sistemlere uyum sağlayabilirler.

- PLC'lerin arıza oranları düşüktür ve çok sık bakım istemezler.

- PLC'lerin enerji tüketimleri çok tasarrufludur.

- PLC'ler kullanıcı dostudur, gereken yerlerde kullanıcının müdahalesi kolaydır.

- PLC'ler sınırsız zamanlayıcı, sayıcı, kontak, kullanımına imkân tanır.

Şekil 1'de endüstriyel otomasyon sistemlerinde kullanılan kumanda devrelerini gösteren örnek görüntüler sunulmaktadır. Şekil 1(a), eskiden kullanılan röleli kumanda sistemini, Şekil 1(b) PLC dönüşümü yapılmış kumanda sistemini sunmaktadır. Eski kumanda devrelerinde kullanılan rölelerin yerine sanal olarak girdi, çıktı, zamanlayıcı, mantıksal ve (and) / veya (or) kapıları gibi çeşitli bileşenler kullanılarak yerden ve zamandan tasarruf sağlanmıştır.

Literatürde PLC kullanılarak gerçekleştirilmiş çok sayıda çalışma yer almaktadır. Termal simülasyon kontrol sistemlerinde kapalı döngü kontrol görevleri için termal simülatörün kontrol sistemini tasarlamada PLC kontrol cihazı, servo kontrol sistemi ve yeni nesil gerçek zamanlı haberleşme teknolojisi kullanılmıştır. Tüm kontrol sistemi, kırıcının pozisyon kontrolünü, doğrudan dirençli ve indüksiyon ısıtma altındaki sıcaklık kontrolünü, yüksek hızlı veri toplama, veri analizi ve işleme görevlerini verimli bir şekilde tamamlar (Su ve ark., 2019). 


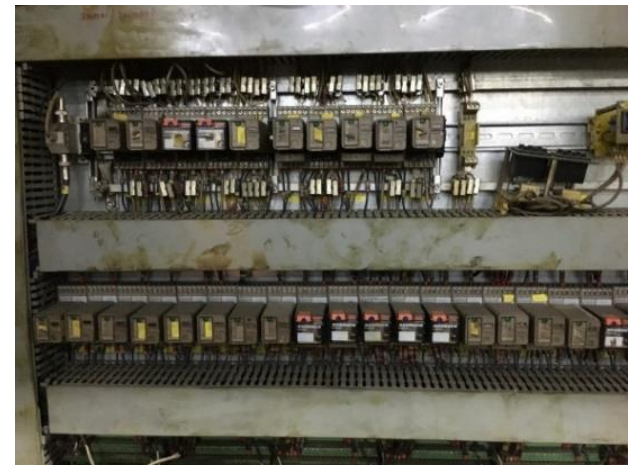

(a) Röleli kumanda sistemi

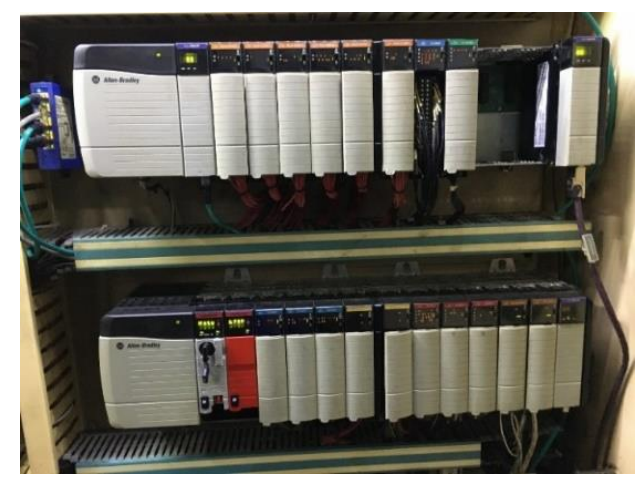

(b) PLC dönüşümü yapılmış kumanda sistemi

\section{Şekil 1. Endüstriyel otomasyon sistemlerinde kullanılan kumanda devreleri}

PLC otomasyon sistemleri mevcut manuel üretim sistemini geliştirmek için tamamen kendinden kontrollü yeniden yapılandırılabilir süreçlerle değiştirmeye çalışır. Endüstri 4.0 (Endüstri 4.0 bir hedeftir ve bilişim teknolojileri ile tüm yaşamsal mekanizmaları bir arayı getirmeyi amaçlamaktadır.) temel kavramlarını uygulayarak üretimi yakından izlemek, manuel kontrolü azaltmak ve küçük bir içecek tesisinin şişeleme sürecini verimli bir şekilde izlemek için bir strateji geliştirmektedir. Geliştirilen strateji, günlük üretimi zamanın bir fonksiyonu olarak yapılandırarak ve hedefe ulaşılmadığında sistemi otomatik olarak artırmak için programlama koşulları uygulayarak üretimi günlük hedefe mümkün olduğunca yakınlaştırır. Otomatik parametre yapılandırma stratejisi, üretim sonuçlarının ve izleme bilgilerinin yalnızca tesisteki merkezi bir SCADA sisteminde mevcut olduğu kapalı bir ağda oluşturulmuştur. Bunun için ZENON SCADA ve HMI ile Ethernet TCP / IP üzerinden iletişim kuran bir Siemens S7-1200 PLC kullanılmıştır. Gelecekteki çalışmalar için, merkezi olmayan bir sunucudan veya internet servislerini kullanarak tesis bilgilerinin izlenmesine izin verecek şekilde gerekli uygulamalar ve protokoller yapılandırılabilir (Kingala ve ark., 2019).

Bir ağ uygulamasına dayalı modüler bir üretim tesisinin tasarımı için ürün odaklı bir ağ sunucu üzerinden OPC (OLE for Process Control) UA tabanlı kontrol sistemi, üretilen reçete bilgilerini (çalışma zamanı, hız ve adet bilgileri) kodunu PLC otomasyon sistemi okuyarak yorumlayıp üretim hattını çalıştırmaktadır. Bu şekilde bu üretim tesisinde hibrit karbon fiber koltuk ürünü sorunsuz bir şekilde üretilmiştir (Schäfer ve ark., 2019).

PLC ve SCADA tabanlı otomasyon kontrol sistemleri sayesinde dozajlaması yapılan malzemenin anlık bilgileri, çalışma parametrelerini önemli ölçüde etkilediğinde, bu parametrelerin PLC ile kontrol edilmesi sonucu akıllı ve hassas sistemler oluşturularak yüksek verimli dozajlama makineleri üretilebilmektedir. $\mathrm{Bu}$ sayede endüstriyel boyaların istenilen oranlarda ve farklı aralıklardaki renklerin dozajlama sistemiyle karıştırılmasına olanak sağlamıştır (Kafalı, 2019).

Bir tesiste açık ve düşük voltajlı elektrik şebekelerinin veri iletişimi amaciyla karakterize edilmesi ve modellenmesi için yürütülen kapsamlı bir ölçüm yapılmaktadır. Bu bağlamda, ortalama kanal zayıflaması, kök-ortalama-kare gecikme yayılımı, tutarlılık süresi, tutarlılık bant genişliği ve ulaşılabilir veri hızı istatistikleri dikkate alınarak analiz edilir. Bu düşük voltajlı elektrik şebekelerinin periyodik değişimi ölçülür ve ortalama kanal zayıflamasının geçici bir fonksiyonu olarak sunulur. Sayısal analizlerden elde edilen sonuçlar, veri iletişimi amaciyla Brezilya da dış mekân ve düşük voltajlı elektrik şebekeleri hakkında önemli bilgiler PLC aracilı̆̆ıla kontrol edilmektedir (Picorone ve ark., 2020). Diğer bir çalışmada ise, Waijung blok setleri ve STM32FT Mikro denetleyicisi kullanarak bulanık mantık temelli PLC tarafindan kontrol edilen oda sıcaklık kontrolü çalışması yapılmıştır. Yapılan bu simülasyon çalışmasında bulanık teoriye dayalı bir odanın sıcaklık ve nem kontrolü sağlanmıştır (Tosun ve ark., 2019).

Giriş ve çıkış parametrelerinin PLC tarafindan alınıp sayısal verileri bulanıklaştırılması, bulanık mantığın kural seti sayesinde araba sayısına göre yeşil ışığın süresi ve cadde seçiminde akıllı bir kontrol sistemi elde etmemizi sağlayabilmiştir. Aynı verileri klasik yöntemde de kullanarak, bulanık mantık ve PLC kontrol yönteminin klasik yönteminden daha etkin olduğu görülmüştür (Anas ve ark., 2019). Literatürde yer alan bazı endüstriyel uygulamada görüntü işleme teknikleri ve PLC ile senkron çalışması gerçekleştirilmiştir. $\mathrm{Bu}$ çalışmalar sonucunda, endüstriyel otomasyon sektöründe vazgeçilmez ürünler arasında yer alan PLC'ler, bir konveyör sisteminde gerçek zamanlı olarak veya bir robot kol kullanılarak renkli nesnelerde ayrıştırma yapmak amacıyla da kullanılmıştır (Şengül ve ark., 2020; Hız, 2019).

Yapılan bir tez çalışmasında engelli bireylerin başka kimseye ihtiyaç duymadan kendi ihtiyaçlarını giderebilmesi için otomasyonlu akıllı ev sistemleri yapılmıştır. Tasarlanan sistemde birinci derece omurilik felçli bireyler göz bebeklerini hareket ettirerek evlerinin ihtiyaç duydukları aksamlarını kontrol edebilecek otomasyon sistemi tasarlanmıştır. $\mathrm{Bu}$ işlemleri gerçekleştirebilmek için tasarlanan sistemde PLC S7-1200, yazılım olarak WinCC SCADA ve kamera kullanılmıştır (Kivilcim, 2019).

Yapılan çalışmada yerden insanlı firlatma uzay araçlarının firlatma öncesi aşamasındaki acil kaçış kontrol tasarımı yüksek güvenirlikli PLC tarafından sağlanmıştır. "Veri giriş modülü", "mantık kontrol modülü" ve "işlev modülü" oluşturularak, acil durum kaçış komutları doğru bir şekilde iletilebilir; aynı zamanda, yedeklilik tasarımı, filtreleme tasarımı ve diğer güvenilirlik tasarım önlemleri ile birlikte, astronotların ilk tehlike anında hızlı ve güvenilir bir şekilde kaçmasını garanti edebilecek daha az sistem kaynağı ve yüksek verimlilik hedefi gerçekleştirilmiştir (Wang, Z. Y., \& Ren, Y. H. 2020).

Makale çalışması kapsamında, PLC yapısı, kullanım avantajları, geliştirme ortamları detaylı bir şekilde incelenmiştir. Ayrıca, lastik üretim tesislerinde yer alan Mill makinelerinin güvenli bir şekilde çalışması amacıyla PLC, HMI ve giriş/çıkış kartları kullanılarak örnek çalışma gerçekleştirilmiştir. Makalenin ikinci bölümünde PLC genel yapısı, üçüncü bölümde 
programlama dilleri, dördüncü bölümde gerçekleştirilen çalışma ve son bölümde elde edilen sonuçlar sunulmaktadır.

\section{PLC Genel Yapısı}

PLC giriş ve çıkış cihazlarının durumunu sürekli olarak izleyen ve kontrol eden içinde yüklü olan programa dayalı kararlar veren bir mikro bilgisayardır (Aydoğdu ve ark., 2019). PLC lerin içinde verileri işlemek için bir işlemci (CPU), verileri saklamak için bir geçici belleği (RAM) ve yazdığımız programları saklamak için de kalıcı bellek (ROM) bulunmaktadır. PLC'ler genellikle karmaşık otomasyon problemlerini çok hızlı ve güvenilir bir şekilde çözdüğü için kullanılmaktadır. PLC'lerde otomasyon sistemlerini kontrol etmek ve yönetmek için birçok giriş (input) ve çıkış (output) bulunmaktadır (Nazım, 2020). PLC ler mikroişlemci tabanlı otomasyon sistemlerinde problemleri hızlı ve güvenilir şekilde çözmeye yarayan mükemmel sistemlerdir. Şekil 2'de PLC ye ait genel yapı ve bileşenleri sunulmaktadır.

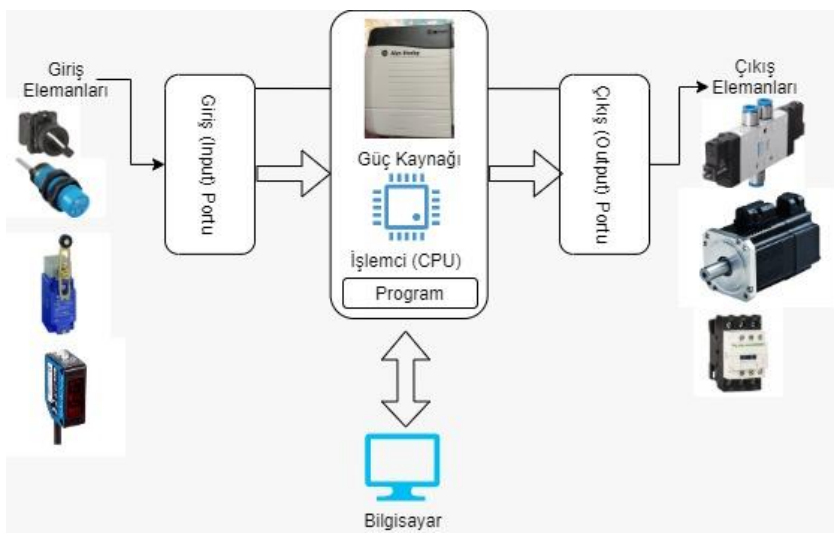

Şekil 2. PLC genel yapısı ve bileşenleri

Şekil 2'de görüldüğü üzere PLC'ler temel prensip olarak üç birimden oluşmaktadır. Bunlar merkezi işlem birimi (CPU), bütün sinyal elemanlarının bağlandığı giriş belleği ve kumanda edilecek elemanların bağlandığ 1 çıkış belleğidir (Eminoğlu, 2013).

Giriş belleği, kontrol edilen otomasyon sistemlerinden algılayıcılar, düğmeler, sınır anahtarları gibi cihazlardan alınan basınç, sıcaklık gibi elektriksel sinyalleri mantıksal değerlere dönüştürerek CPU' ya aktaran sistemlerdir (Eminoğlu, 2014). PLC'lerin bu girişten alınan elektrik sinyalleri hem sayısal hem de analog olabilir. PLC'lerin model marka ve yapılarına göre giriş sinyalleri $24 \mathrm{~V}$ veya $110 \mathrm{~V}$ olabilir. Sayısal giriş sinyalleri CPU tarafindan 1 ve 0 olarak yorumlanmaktadır (Karayel, 2013). PLC'lerde giriş belleği, opto kuplörler kullanılarak izole edilmektedir.

CPU, PLC, program ve sistemin çalışmasını düzenleyen ve kontrol eden birimdir. Giriş belleğinden aldığı sayısal veya analog programın yapısına göre yorumlamaktadır. Sonrasında, çıkış belleği aracılığı ile kontrol aygitlarına uygun komutları göndermektedir (Kafalı, 2019). CPU hızı PLC'lerin marka ve modeline göre değişim göstermektedir.

Çıkış belleği, kendine gelen sayısal veya analog sinyalleri, elektriksel sinyallere dönüştürülerek çıkış birimlerinde yer alan motorlar, bobin valfler, kontaktörler, röleler gibi cihazları kontrol etmektedir. Cihazlara gönderilen çıkış sinyalleri doğru akımda DC. transistor veya alternatif akımda AC. triyak çıkışlı olmaktadır (Özer, 2016). Voltaj aralığı cihazın yapısına göre doğru akım 24V veya alternatif akım $110 \mathrm{~V}$ olmaktadır. Çıkış belleğinden çekilen akım değerleri kontak çıkışlı devreler için 1 ve 8 Amper, triyak ve transistörlü devreler için 0,1 - 2 amper arasında değişmektedir (Çetin, 2004).

PLC bekleme durumundan, çalışma durumuna alındığında ilk olarak çıkış belleği sıfırlanır, daha sonra giriş belleğindeki verileri okur ve hafızasına kaydeder. PLC yazılmış olan programı sürekli yukarıdan aşağıya doğru taramaktadır (Thompson, 1996). Bu tarama döngüsü temel üç adımda gerçekleşir. PLC tekrar bekleme durumuna alınan kadar bu döngü sürekli devam etmektedir. Tarama döngüsü, Şekil 3' sunulduğu üzere, Giriş Belleğinin kontrol edilmesi, Programın yürütülmesi ve Çıkış Belleğinin kontrol edilmesinden oluşmaktadır.

PLC'lerde röle, triyak ve transistör olmak üzere farklı çıkış türleri bulunmaktadır. Kurulacağı sisteme göre PLC çıkış türlerinin seçimine dikkat etmek gerekmektedir. Röle çıkışlı PLC'lerde, hem doğru akımda hem de alternatif akımda kullanılabilir. $\mathrm{Bu}$ çıkışların akımları maksimum 2 amperdir. Cevap verme hızının düşük olması, mekanik hareket olmasından dolayı röle kontaklarının zamanla aşınması dezavantaj olarak görülmektedir. Triyak çıkışlı PLC'ler kontaksız olup, 85V - 242V alternatif gerilim arasında değişmektedir. Tepki süresi röle çıkışlı PLC lere göre daha hızlı ama transistör çıkışlı PLC ler göre de daha yavaştır. Maksimum çıkış akımı 0,3 amperi geçmemektedir (Kurtulan, 2008). Transistor çıkışlı PLC, optokuplör kullanmakta olup çıkış akımları maksimum 0,5 amper ve tepki süreleri 0,2msdir. Bu PLC'lerde transistör kullanıldığı için çıkışında kutuplar mevcuttur. Genellikle otomasyon sistemlerinde çıkışları çok hızlı olduğu için transistör çıkışlı PLC'ler tercih edilmektedir.

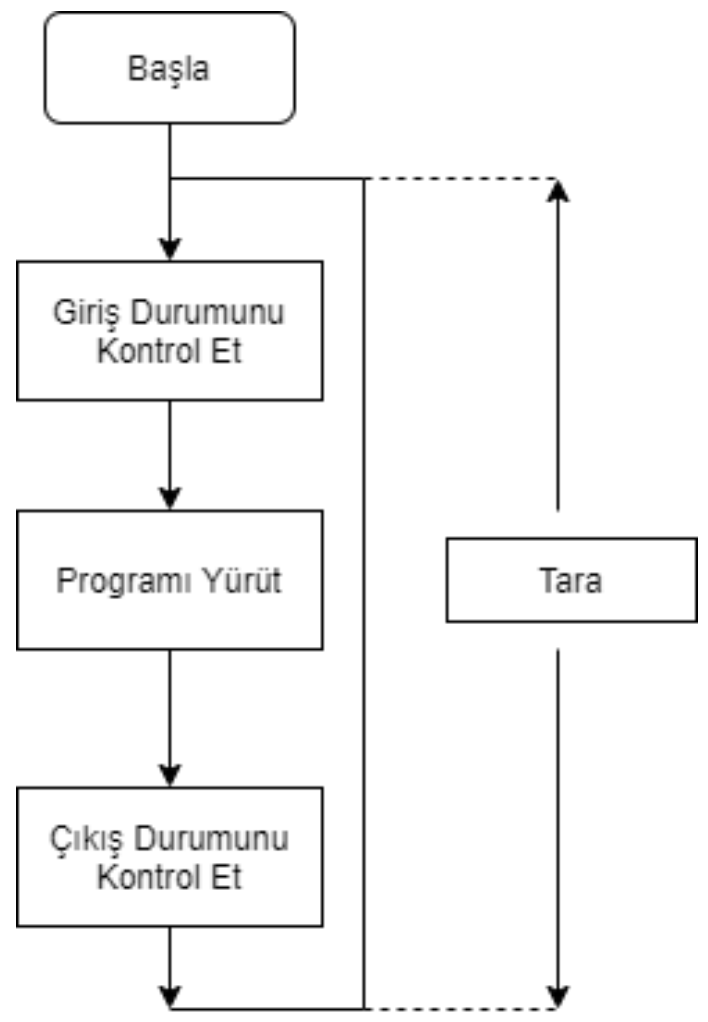

Şekil 3. Tarama döngüsüne ait akış şeması

\section{PLC Programlama Dilleri}

PLC'ler, kontrol ve kumanda sistemlerini uygun bir programlama dili kullanarak istenildiği gibi kontrol etmektedir. PLC'ler kullanıcıların kolayca uyum sağlayıp yazabilecekleri birçok programlama dillerine sahiptirler. Yaygın olarak 
kullanılanlar, Merdiven Diyagramı (LAD: Ladder Diagram), Fonksiyon Blok Diyagramı (FBD: Function Block Diagrams), Komut (STL: Statement List, IL: Instruction List), Yapisal Metin Dili (ST: Structured Text), Ardışıl Fonksiyon Gösterimi (SFC: Sequential Functions Charts) dir (Eminoğlu, 2013).

Merdiven diyagramı normal elektriksel kumanda devrelerine benzemektedir. Program soldan sağa doğru açık / kapalı kontak, çıkış röle gibi şekiller konularak yazılır. Merdiven diyagramının çalışma mantığı sol taraftan enerji verilerek sağ taraftan çıkış elde edilmesine dayanmaktadır. Elektriksel kumanda devrelerine benzediğinden kolay ve çok tercih edilen program türüdür (Nguyen, 2020). Şekil 4. RSLogix 5000 PLC de Mill makinasının acil durdurma program merdiven diyagramı ve akış şeması gösterilmiştir.

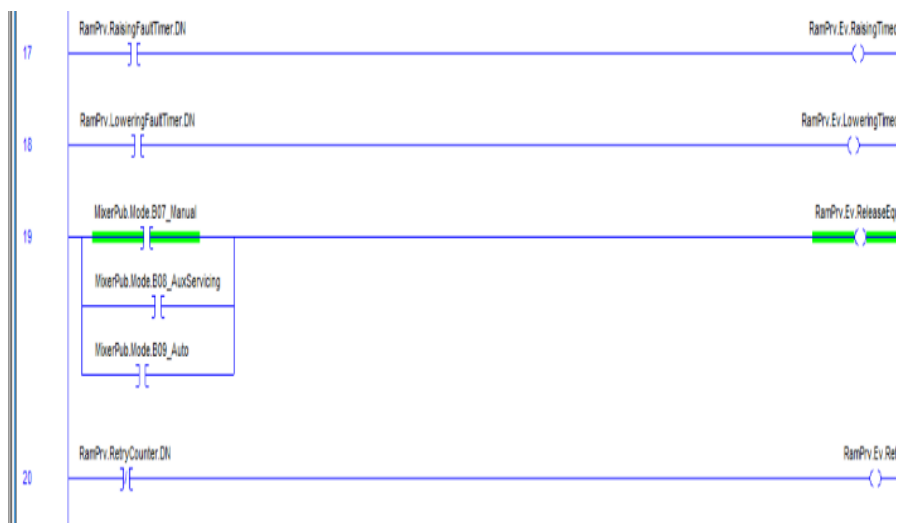

(a) Merdiven diyagramı

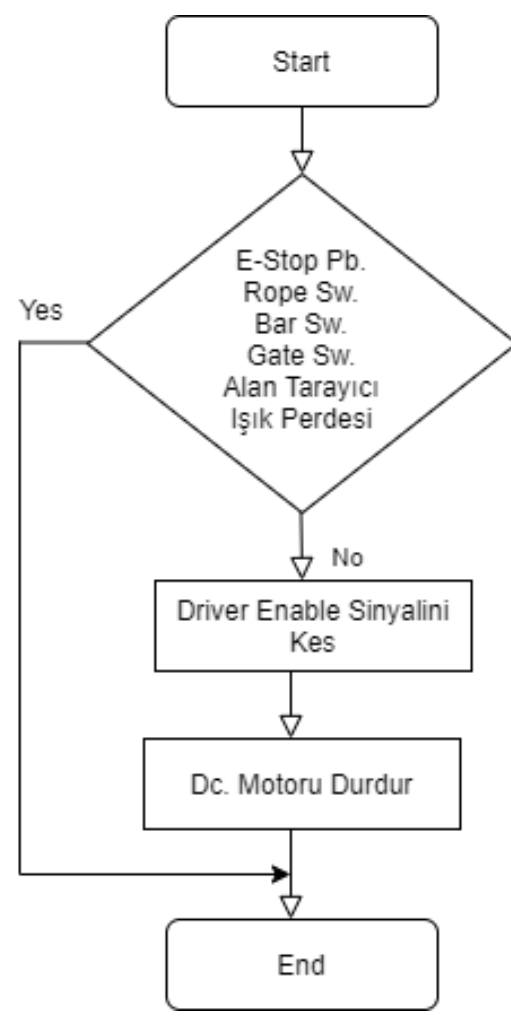

(b) Akış Diyagramı

Şekil 4. Mill makinasının acil durdurma program merdiven ve akıs diyagramı

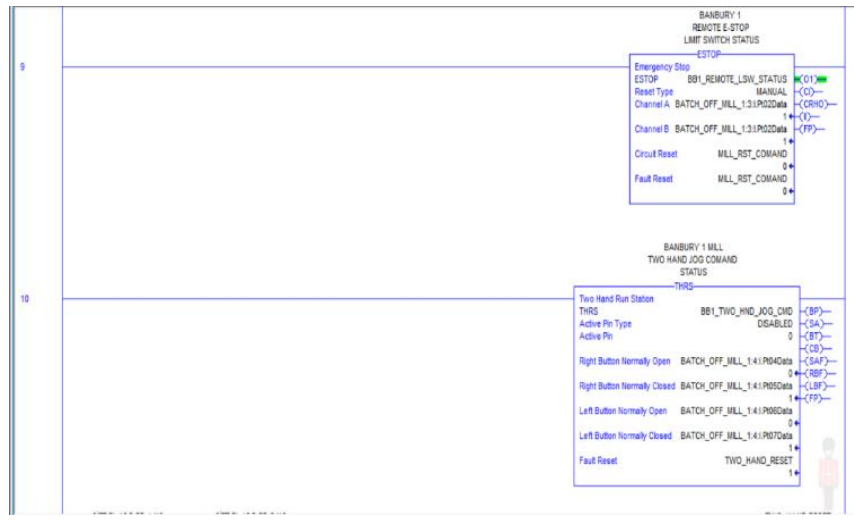

Şekil 5. Fonksiyon blok diyagramı

Fonksiyon blok diyagramı genellikle mantıksal ve lojik kapıların kullanıldığı görsel bir programlama dilidir. FBD programlama dilinde kutularla simgelenen mantık kapıları kullanılmaktadır. $\mathrm{Bu}$ programlama dilinde ise giriş sinyalleri soldan başlar çıkış sinyalleri sağda biter. Kontrol sistemi algoritmalarını ve mantığını birbirine bağladığından kullanışlı bir programlama dilidir (Eminoğlu, 2013). Şekil 5 'te fonksiyon blok diyagramı kullanılarak gerçekleştirilen örnek bir program parçası sunulmaktadır.

Yapısal metin dili, Pascal veya $\mathrm{C}$ programlama diline benzeyen yüksek düzeyli bir programlama dilidir. Her PLC programında kullanılmaz. Ardışıl fonksiyon gösterimi programlama dili, kumanda devrelerinin doğrudan gerçekleşmesi için oluşturulmuş bir programlama dilidir. Fransa da kullanılan Grafcet programlama diline benzer ve her PLC programinda kullanılmaz. Tüm PLC türlerinde programlama dilleri benzer özellikler taşımaktadır.

\section{Mill Makinesinde İş Kazalarının PLC Kullanılarak Önlenmesi}

Makale kapsamında, lastik üretim tesisinde lastiğin ham maddesi olan kauçuğun karışım hale getirilerek hamur halinde büyük ebatlardaki Mill makinalarının eski otomasyon kumanda sisteminin PLC dönüşümü gerçekleştirilmiştir. Mill makinesine, PLC, giriş, çıkış kartları ekleyerek yeni otomasyon sistemine dönüştürülmüş ve iş kazası yapma riskini minimum seviyeye getirilmiştir. Ayrıca bu yeni sisteme uygun yeni nesil güvenlik cihazları eklenerek PLC ile haberleşmesi sağlanmıştır. Yapılan bu çalışmadaki amaç üretimin kaliteli, hızlı yapılması ve çalışanların iş kazasına uğrama riskinin azaltılması sağlanmıştır. $\mathrm{Bu}$ makinalarda güçlü DC motorlar (TECO-Westinghouse Direct Current DC motors 22 -inch $250 \mathrm{hp}$ ) yardımıyla büyük ebatlardaki iki milin arasındaki lastik hamurlar ezilerek istenilen inceliğe getirilmektedir. Mill makinaları 1960 yapımı olduğu için o zamanın şartlarına göre üzerindeki kullanılan mevcut ekipmanlar iş güvenliği kategori 4 standartlarına uygun değildi. Önceki sistemde iş güvenliği ekipmanı olarak mill makinasının önünde uzun bir basinca duyarlı limit anahtara basan metal bar, operatörün kumanda panelinde mantar başlı buton ve çekmeye duyarlı tel limit anahtarlar bulunmaktaydı. Basınca duyarlı metal barın bastığı limit anahtarlar iş güvenliği standartlarına uygun değildi. Bu ekipmanlar zamanla toz ve nemin etkisiyle kontakları oksitlenmekte ve gereken giriş değeri iletilemez duruma gelmekteydi. Bu ekipmanlar iş kazası riskini minimuma indirecek seviyede değildi. Operatör çalışırken barın altından veya üstünden kapılırsa sistemi durduracak ekipman mevcut değildi. Mevcut ekipmanların hepsi iş güvenliğine uygun kategori 4 105 
standartlarında ekipmanlar ile değiştirilip ek olarak 1şık perdeleri ve alan tarayıcı ilave edildi. Bu ekipmanların durumları PLC tarafindan gözlemlenebilir hale getirilip arıza yapma durumları halinde çalışan sistemi durdurması sağlanmış oldu. Yapılan bu çalışmada yukarıda bahsedilen tehlikeler ortadan kaldırılmış olup iş kazası yapma riski minimuma indirilmiştir. Sistemde kullanılan 1şık perdeleri ve alan tarayıcılar her zaman etkin durumdadır. Operatörün gövdesi 1şı bariyerini $270 \mathrm{~mm}$ 'den fazla yaklaşırsa taranan alandan çıktıktan sonra sistemi sıfırlamak gerekir. Eğer sistem sıfirlanmazsa operatörün mille kapıldığını düşünüp makinayı durdurmaktadır. Operatör, taranan alandan sisteme sıfırlamadan ayrılırsa, mill motoru durmaktadır. Operatör taranan alanın üzerinden atlamaya çalışırsa, ışık perdesi algılanır ve mill motoru doğrudan durur. Sistemin güvenliğini sağlamak için tasarlanan senaryolar iş kazası riskini en aza indirmek için kullanılmaktadır.

Limit anahtarlar bir makine parçasının ya da bir nesnenin hareketi, dokunması, çarpması ile çalışan elektromekanik cihazlardır. Mekanik bir etkiyi elektriksel bilgiye çevirirler. Standart bir limit anahtar, bir aktüatör ve buna seri olarak bağlı kontaklardan oluşur. Bir cisim aktüatöre dokunduğunda limit anahtarın kontakları konum değiştirmekte ve bağlı olduğu devrenin elektrik bağlantısını kesmektedir (Waugh, 2020).

Şekil 6 deki gibi kullanılan limit anahtarlar in normalde açık (no) ve normalde kapalı (no) kontakları bulunmaktadır. $\mathrm{Bu}$ kontaklara bağlı elektrik kabloları emniyet rölesine bağlanmaktadır. Limit anahtarlar in kontaklarının konum değiştirmesiyle bağlı olduğu emniyet rölesi millin dönmesini sağlayan DC motoru süren sürücünün bağlı olduğu çalışmasına izin veren kontaktörü düşürmektedir. Böylece sürücü sürdüğü DC motoru dolayısıyla makinayı durdurmaktadır.
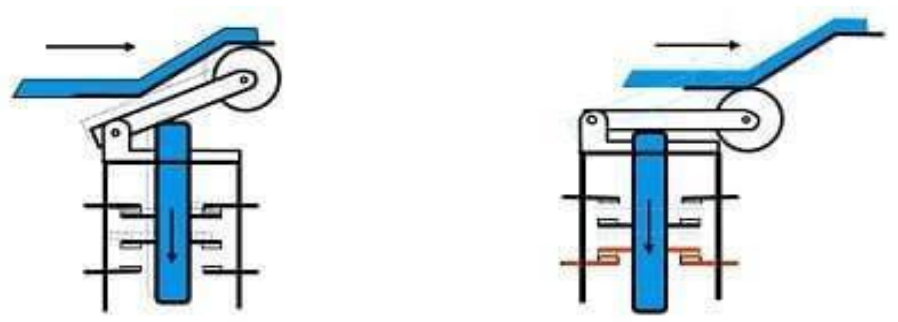

Şekil 6. Limit anahtar çalışma prensibi (Anon., 2020a)

Gerçekleştirilen çalışmada Mill makinasına, temassız güvenlik anahtarları, güvenlik lazer alan tarayıcıları ve güvenli 1ş1k bariyerleri eklenmiştir. Şekil 7(a)'da sunulduğu üzere RE1 manyetik güvenlik anahtarları açı/kapalı kontaklarla veya kodlanmış manyetik aktüatörlerle doğrudan etkileşime giren, eşdeğer açık kontaklarla donatılmaktadır. Bu manyetik güvenlik anahtarları, yüksek toleranslara izin verdiğinden, güvenlik cihazlarının tam olarak idaresinin zor olduğu yerler için uygundur. Şekil 7(b)'de yer alana microScan3 güvenli lazer alan tarayıc1, basitten karmaşığa kadar çok farklı sabit ve mobil uygulamanın korunmasını sağlamaktadır. Kompakt yapı şekli ve yüksek tarama mesafesi sunan teknoloji sayesinde, microScan3'ün zorlu ortam koşullarında da bakış açısını korumasını sağlanmaktadır. Şekil 7(c)'de sunulan C4000 Advanced ATEX II 3G/3D güvenli 1 şı bariyeri tehlikeli noktaları ve alanları, patlama riski oluşan atmosferlerde dahi ekonomik ve güvenilir biçimde emniyete almaktadır (Anon., 2020b).
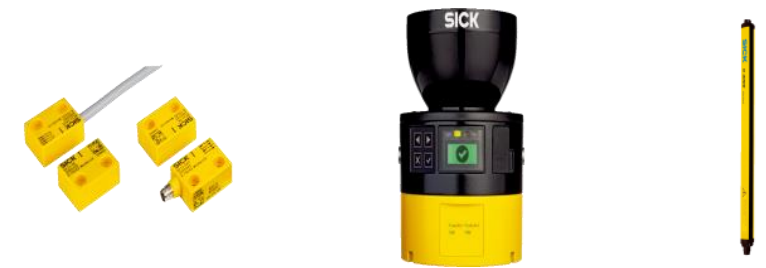

(a) Temassız güvenlik

(b) Güvenlik lazer alan anahtarl

tarayıcı

(c) Güvenli ışık bariyeri

Ayrıca çalışmada oluşturulan PLC konfigürasyonu, PLC CPU Safety özelliklerine sahip Rockwell 1756-L73S ve Partner CPU 1756-L7SP eklenmiştir. Bu cihazlar, üretim için akıllı makinelerin ve ekipmanların artan taleplerini karşılamaya yardımcı olmak üzere artırılmış performans, kapasite, verimlilik ve güvenlik sağlamaktadır. Cihazlar verimliliği optimize eden, hizmete alma süresini kısaltan standart çerçeve olarak Studio 5000 tasarım ortamını kullanmaktadır. Bu çerçeve, yüksek hızlı hareket uygulamaları ve SIL2 / PLd ve SIL3 / PLe güvenlik çözümleri için EtherNet / IP üzerinden bütünleşik hareketi yönetmektedir. $\mathrm{Bu}$ kontrolörler 256 eksene kadar yüksek performanslı iletişim, I / O ve hareket kontrolü gerektiren uygulamalar için idealdir. Bunların yanı sıra, 7 adet 1734-IB8S güvenlikli giriş kartı, 1 adet 1734-OB8S güvenlikli çıkış kartı, 3 adet 1734-OB8 sayısal çıkış kartı ve 1 adet 1734-IB8 sayısal giriş kartı eklenmiştir.

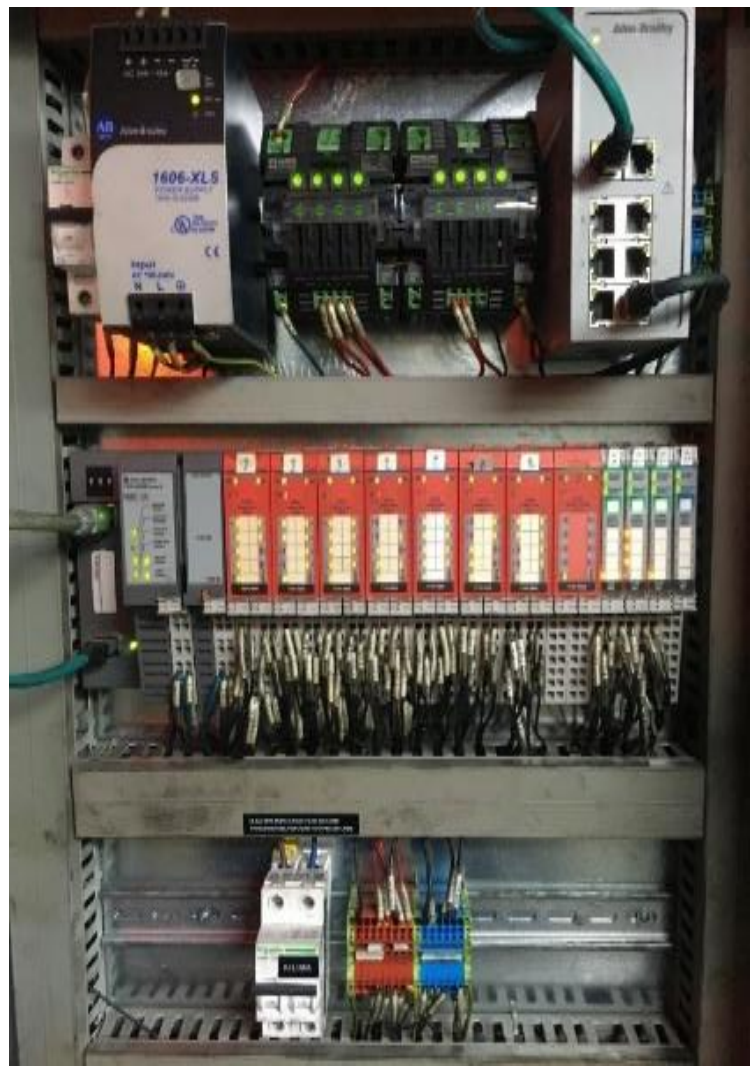

Şekil 8. . Mill Makinesi güvenli PLC I/O paneli

Şekil 8'de Mill makinasının güvenli PLC giriş ve çıkışların bulunduğu panel sunulmaktadır. Burada makinaya eklenen PLC giriş elemanları ve çıkış elemanları bağlanmaktadır. Ana PLC ile iletişimi Rockwell 1734-AENTR kartı kullanılarak EtherNet / IP haberleşmesi üzerinden yapılmaktadır. Mill makinesinde kullanılan PLC giriş ve çıkış güvenlik ekipmanları maddeler halinde sunulmaktadir. 
1. Wigvag operatör acil durdurma butonu

2. Wigvag alt kat ipli emniyet anahtarı

3. Soğutma konveyör mal dayandı limit anahtarı

4. Wigvag kapı plak güvenlik anahtarı

5. Soğutma konveyör kapı anahtarı

6. Soğutma konveyör alt kat kapı anahtarı

7. Soğutma konveyör alt kat ipli emniyet anahtarı

8. Ișık Perdesi

9. Mill çarpmalı emniyet sensörü sağ taraf

10. Ayak pedalı

11. Mill çarpmalı emniyet sensörü sol taraf

12. Diğer mill durdurma ipli emniyet anahtarı

13. Mill üstü aktarma konveyör ipli emniyet anahtarı

14. Mill kontrol panel acil durdurma butonu

15. Alt kat soğutma konveyör panel acil durdurma butonu

16. Çit el butonu

Şekil 9(a)'da Mill makinasında PLC güvenlik dönüşüm projesinde yazılan programa toplamda 13 adet giriş / çıkış kartlarının dizilimi görülmektedir. PLC'de program yazmaya başlamadan önce sisteme, kullanılacak giriş/çıkış kartları tanitılması gerekmektedir. Sonrasında planlanan senaryoya göre programın yazılımına başlanmaktadır. Şekil 9(b)'de görüldüğü üzere program Merdiven diyagramı üzerine yazılmıştır. PLC girdileri ESTOP fonksiyonun da oluşturulmaktadır. Güvenlik uygulamalarında kullanılması amaçlanan yazılım programlanabilir bir ortamda güvenlik rölesinin giriş işlevselliğini taklit etmek için acil durdurma (ESTOP) talimatını kullanmaktadır. Bu operasyonda, iki giriş kanalının durumunu izlemekte ve resetleme koşulları gerçekleştiğinde Çıkış 1'i açmaktadır.

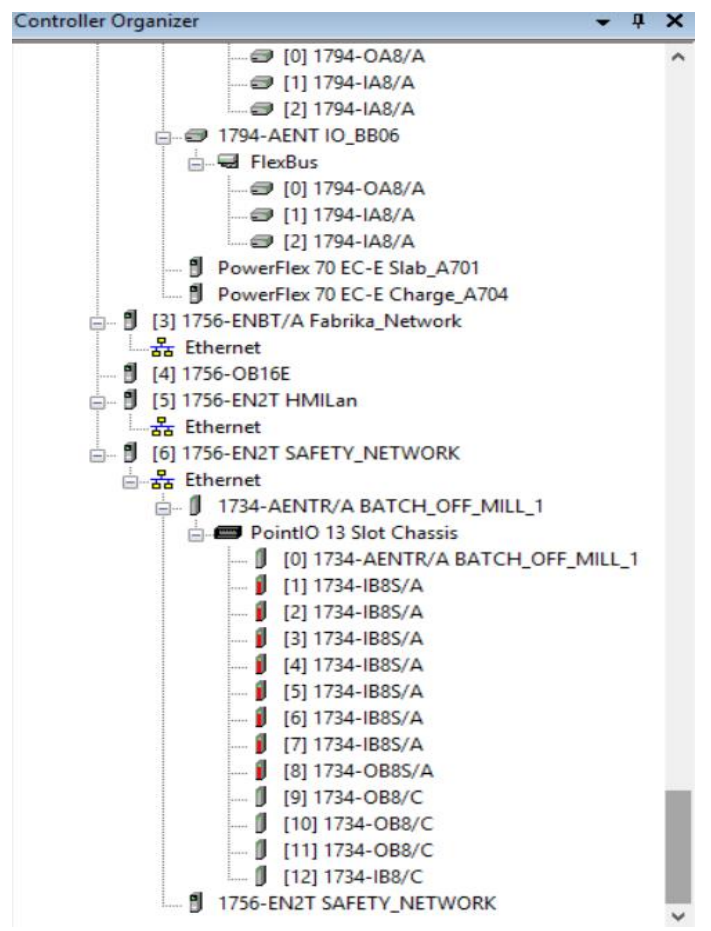

(a) Giriş/çıkış kartları dizilimi

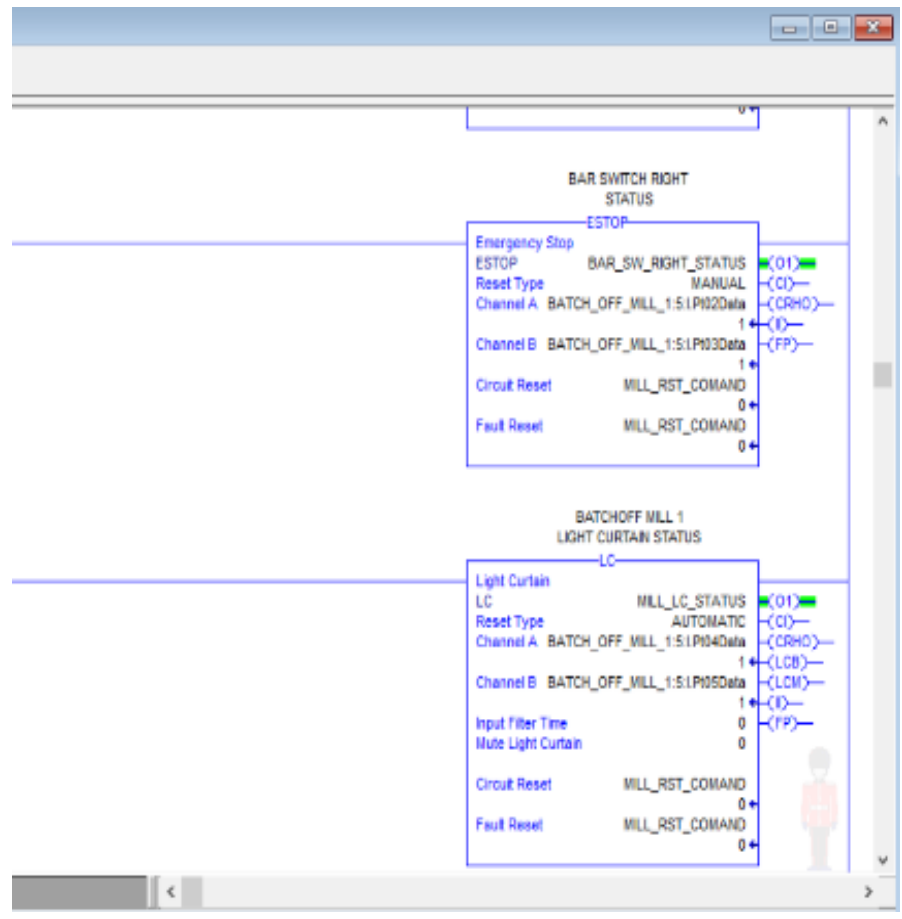

(b) Programin yazılması

Şekil 9. Güvenli PLC giriş/çıkış dizilimi ve programın geliştirilmesi

Acil resetleme kullanılırken, her iki giriş de aktif durumdadır ve devre resetleme girişi sıfırdan bire geçmektedir. Otomatik resetleme kullanılırken, her iki giriş de $50 \mathrm{~ms}$ boyunca aktif durumdadır. Bu fonksiyonun giriş kanallarından biri veya her ikisi de güvenli duruma döndüğünde Çıkış 1 kapatılmaktadır. Acil durdurma (ESTOP) komutu için her iki giriş kanalı normalde durumda açık olmaktadır. Bu, her iki kanaldaki girdilerin güvenli durumunu ve her iki kanalın da aktif durumunu temsil ettiği anlamına gelmektedir. Normal çalışma durumu değişiklikleri şekil 10 'da zamanlama şemalarında gösterilmiştir.
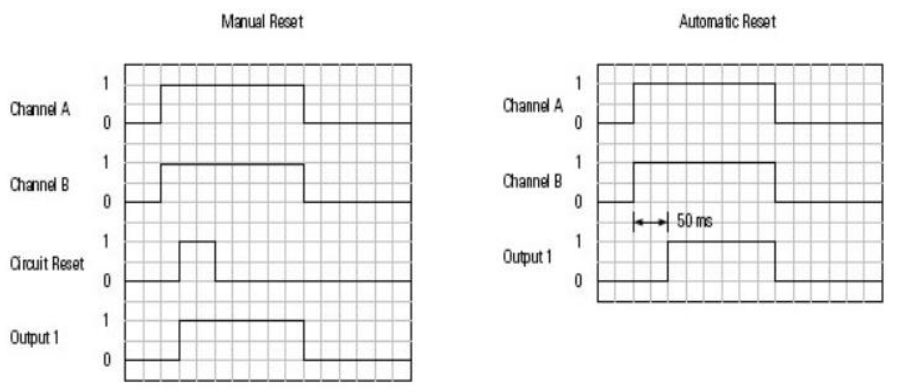

\section{Şekil 10. Acil durum resetleme zaman grafiği}

Acil resetleme kablolaması ve programlaması ile acil durdurma şekil 11(a)'da sunulan şemadaki gibi yapılmaktadır. Makinada bulunan normalde açık iki kontağı olan 2 kanallı acil durdurma anahtarının EN954-1 kategori 4'e uymak için 1791DS güvenlik giriş / çıkış modülüne nasıl bağlanacağı şekil 11(a)'da gösterilmiştir. Şekil 11(b)'de acil durdurma fonksiyon bloğu sunulmaktadır. 


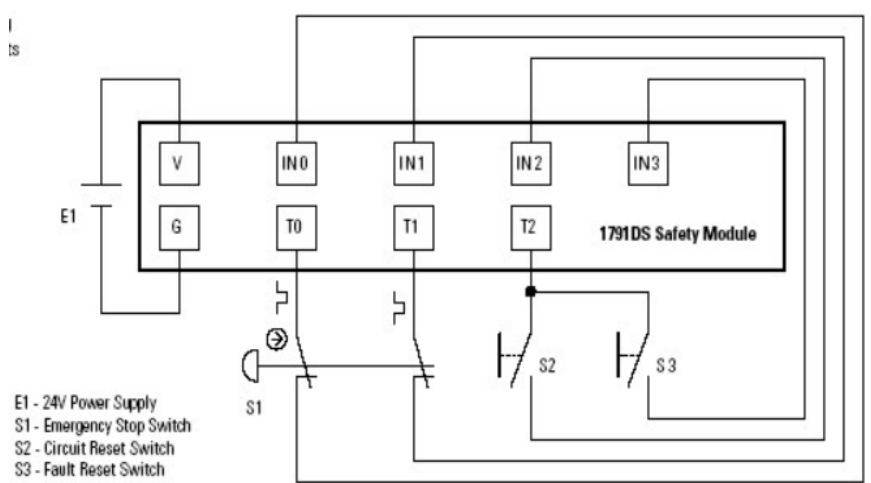

(a) Acil durdurma şeması

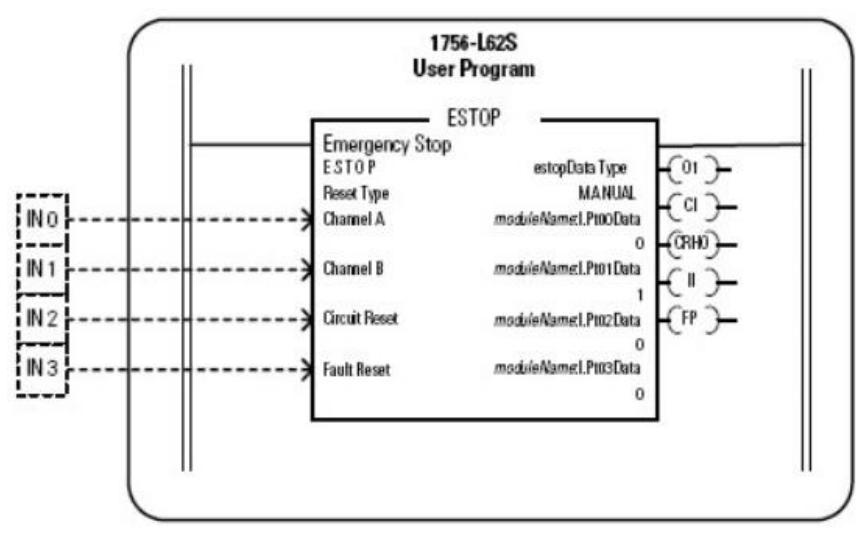

(b) Acil durdurma fonksiyon bloğu

\section{Şekil 11. Acil durdurma şeması ve fonksiyon bloğu}

Gerçekleştirilen ESTOP fonksiyon bloğunda ESTOP parametresine kullanılacak veri türü etiketi tanımlanmaktadır. Reset tipi kısmında komutun çıkışı bir için manuel veya otomatik resetleme kullanıp kullanmadığını belirlenir. Kanal-A ve B giriş kısmı normalde açık kontak olmalıdır. Acil durdurma butonuna basıldığında sayısal değer bir den sıfira düşmektedir. Manuel resetleme kısmina Kanal A ve B'nin güvenli durumdan etkin duruma geçmesinden ve devre resetleme girişinin sıfırdan bire geçişinden sonra çıkış bir olarak ayarlanmaktadır. Hata resetleme parametresi komut için arıza koşulları düzeltildikten sonra, bu giriş kapalı durumdan açık konuma geçerken komut için hata çıkışları silinmektedir. Çıkış 1 parametresi, giriş koşulları sağlandığında çıkış 1 aktif durumuna ayarlanır. Acil durum söz konusu olduğunda çıkış sıfıra düşer, emniyetli duruma geçtikten sonra resetlenip çıkış bir konumuna geçmektedir.

RSLogix 5000 programında 1şık perdeleri ve lazer tarayıcılar için LC (Light Curtain) fonksiyonu oluşturulmuştur. Bu fonksiyonun çalışma prensibi, programlanabilir bir kontrolörden SIL3, PLe / Kategori 4 güvenlik uygulamalarında kullanılan bir 1 şık perdesine manuel ve otomatik devre resetleme arayüzü sağlamak için ışık perdesi (LC) talimatını kullanmaktadır. Birçok 1ş1k perdesi OSSD1 ve OSSD2 olan iki çıkışı test etmektedir. Bu çıkışlar doğrudan güvenlik kontrolörü girişlerine bağlanırsa, pals testinin filtrelenmesi gerekir. $\mathrm{Bu}$ fonksiyon, iki giriş kanalının durumunu izler ve manuel/otomatik resetleme koşulları gerçekleştiğinde çıkış 1 'i açmaktadır.

PLC, giriş/çıkış ve güvenlik ekipmanları kullanılarak gerçekleştirilen yazılımın kontrolünün ve takibinin etkili bir şekilde gerçekleştirilmesi amacıyla HMI arayüz oluşturulmuştur. HMI ekran içinde işletim sistemi barındıran ve insan-makine arayüzü olarak da nitelendirilen bilgisayarlardır. PLC ile kullanıcı arasındaki gerekli bilgilendirme ve kontrol işlemleri için kullanılmaktadır. Çalışmada kullanılan PanelView Plus 1000 Grafik Terminali, uygulama durumu bilgilerini grafiksel olarak izlenmesini, kontrol edilmesini ve görüntülenmesini sağlamaktadır. Operatör bu ekranlar sayesinde makinanın bütün güvenlik ekipmanlarını görmekte, ekrana gelen alarmlar sayesinde işlerini etkin bir şekilde takip edebilmektedir. Ayrıca Mill makinasında arıza olması durumunda veya başka sebeplerden dolayı durma meydana geldiğinde, meydana gelen imalat duruşlarında bakımcı gelene kadar nerde ihlalin yapıldığını görüp orda düzeltme yapabilir. Örnek olarak güvenlikli tel limit anahtarı çekildiğinde daha öncesinde nereden çekildiğini operatör göremiyordu. Makinada arıza olduğunu düşünüp bakımcıyı çağırıyordu. Yapılan bu çalışmada ise HMI ekran sayesinde telin nereden çekildiği görüp teli kurup çalışmasına devam edilebilmektedir.

Çalışma kapsamında mill makinesine ait iş güvenliği riskleri $5 \times 5$ matris metoduna göre değerlendirilmiştir. Değerlendirme için kullanılan $5 \times 5$ matris metodu genellikle iki veya çok sayıda değişken arasındaki ilişkinin sebep sonuç değerlendirilmesinde kullanılmaktadır. Tablo 1'de risk kontrol planını ve kontrol hiyerarşisini gösteren risk değerlendirme tablosu sunulmaktadır.

\section{Tablo 1. Risk Değgerlendirme Tablosu}

\begin{tabular}{|c|c|c|c|c|}
\hline \multicolumn{3}{|r|}{ Risk Kontrol Planı } & \multicolumn{2}{|r|}{ Kontrol Hiyerarşisi } \\
\hline $1-2$ & $\begin{array}{c}\text { Önemsiz } \\
\text { Risk }\end{array}$ & Önlem Gerektirmez & A & Kaynağında Önleme \\
\hline $3-4$ & $\begin{array}{l}\text { Düşük } \\
\text { Risk }\end{array}$ & $\begin{array}{l}\text { Önlem Gerektirmez Ancak Sürekli } \\
\text { Gözlemlenmeli }\end{array}$ & B & îkame \\
\hline $5-9$ & Orta Risk & $\begin{array}{l}\text { Maliyetler Gözönüne Alınarak Gerekli } \\
\text { Iyileştirmeler Değerlendirilmelidir }\end{array}$ & C & Mühendislik Kontrolleri \\
\hline $10-15$ & $\begin{array}{l}\text { Yüksek } \\
\text { Risk }\end{array}$ & $\begin{array}{l}7 \text { Çalışma Günü İçinde Önlem } \\
\text { Alınmalı }\end{array}$ & D & Uyarı İşaretleri/ İdari kontroller \\
\hline $16-25$ & $\begin{array}{l}\text { Çok } \\
\text { Yūksek } \\
\text { Risk }\end{array}$ & 24 Saat İçinde Önlem Alınmalı & $\mathrm{E}$ & Kişisel Koruyucu Ekipman \\
\hline
\end{tabular}

Tablo 2'de olasılık ve etki değerlerini gösteren $5 \times 5$ matris metoduna ait tablo sunulmaktadır. Tablo içerisinde yer alan farklı renklerle belirtilmiş değerler risk katsayısını ifade etmektedir. Risk olasılık ve etki katsayılarının çarpımı ile elde edilir.

Tablo 2. 5x5 Matris Metodu Tablosu

\begin{tabular}{|l|l|l|l|l|l|}
\hline Olas1l1k & 1 & 2 & 3 & 4 & 5 \\
\hline 1 & 1 & 2 & 3 & 4 & 5 \\
\hline 2 & 2 & 4 & 6 & 8 & 10 \\
\hline 3 & 3 & 6 & 9 & 12 & 15 \\
\hline 4 & 4 & 8 & 12 & 16 & 20 \\
\hline 5 & 5 & 10 & 15 & 20 & 25 \\
\hline
\end{tabular}

Tablo 3'de Mill makinesine ait 5x5 matris metoduna göre gerçekleştirilen risk analizi sunulmaktadır. Sıkışma tehlikesi, sıcak/soğuk yüzeye temas ve kesilme tehlikesi gibi Mill makinesinde görülebilecek tehlikeler incelenmiştir. PLC kullanılması sonucunda risk puanlarında ve risk derecelerinde iyileşme gerçekleştiği gözlenmektedir. 
Tablo 3. Mill makinesi 5x5 Matris Metodu Risk Analizi Tablosu

\begin{tabular}{|c|c|c|c|c|c|c|c|c|c|c|c|c|c|c|c|c|}
\hline & $\begin{array}{c}\text { Faaliyet } \\
\text { Tanımı/ } \\
\text { Faaliyet } \\
\text { Bölgesi }\end{array}$ & $\begin{array}{c}\text { Görülen } \\
\text { Tehlikele } \\
\mathbf{r}\end{array}$ & Risk & $\begin{array}{l}\text { Tehlike } \\
\text { Kaynağı }\end{array}$ & $\begin{array}{c}\text { Mevcut işlem } \\
\text { Kontrolleri }\end{array}$ & Durum & $\begin{array}{c}\text { Yasal } \\
\text { Mevzuatlar }\end{array}$ & 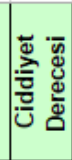 & 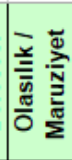 & 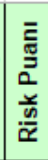 & 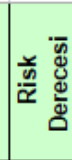 & $\begin{array}{l}\text { Alınacak } \\
\text { Önlemler }\end{array}$ & 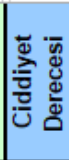 & 5 & & 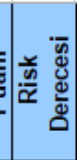 \\
\hline 1 & $\begin{array}{l}\text { Kampound } \\
\text { mille } \\
\text { çalışması }\end{array}$ & $\begin{array}{l}\text { Sıkışma } \\
\text { tehlikesi }\end{array}$ & $\begin{array}{l}\text { Malı verirken, } \\
\text { milleme } \\
\text { operasyonu } \\
\text { sirasında mile } \\
\text { kapilma riski }\end{array}$ & $\begin{array}{l}\text { İnsan } \\
\text { Davranışı } \\
\text { Makine } \\
\text { Malzeme }\end{array}$ & 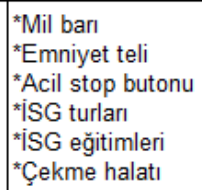 & $\begin{array}{c}\text { Rutin/No } \\
\text { n-Rutin }\end{array}$ & $\begin{array}{l}\text { İşçi Sağlğı ve İ Ş } \\
\text { Güvenliği Kanunu }\end{array}$ & 4 & 4 & 16 & $\frac{\partial}{x}$ & $\begin{array}{l}\text { *Alan Tarayıcı } \\
\text { *Işık perdesi } \\
\text { *Çift kontaklı } \\
\text { digital switchler }\end{array}$ & 3 & 2 & 6 & $\begin{array}{l}\frac{y}{\omega} \\
\frac{r}{\alpha} \\
\frac{\sigma}{\underline{\sigma}} \\
\frac{\sigma}{0}\end{array}$ \\
\hline 2 & $\begin{array}{l}\text { Kampound } \\
\text { mille } \\
\text { çalışması }\end{array}$ & $\begin{array}{l}\text { Sıcak / } \\
\text { soğuk } \\
\text { yüzeyle } \\
\text { temas }\end{array}$ & $\begin{array}{l}\text { Milleme } \\
\text { operasyonu } \\
\text { sırasında }\end{array}$ & $\begin{array}{l}\text { İnsan } \\
\text { Davranışı } \\
\text { Makine } \\
\text { Malzeme }\end{array}$ & 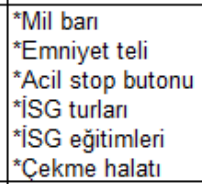 & $\mid \begin{array}{c}\text { Rutin/No } \\
\text { n-Rutin }\end{array}$ & $\begin{array}{l}\text { İşçi Sağlığı ve İş } \\
\text { Güvenliği Kanunu }\end{array}$ & 3 & 3 & 9 & 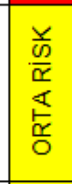 & $\begin{array}{l}\text { *Alan Tarayıcı } \\
\text { *Işı|k perdesi } \\
{ }^{*} \text { Çift kontaklı } \\
\text { digital switchler }\end{array}$ & 3 & 2 & 6 & $\begin{array}{l}\frac{r}{\omega} \\
\frac{\underline{\alpha}}{\alpha} \\
\underline{\underline{\alpha}}\end{array}$ \\
\hline 3 & $\begin{array}{l}\text { Kampound } \\
\text { mille } \\
\text { çalışması }\end{array}$ & $\begin{array}{l}\text { Kesilme } \\
\text { tehlikesi }\end{array}$ & $\begin{array}{l}\text { Kampundu } \\
\text { millden } \\
\text { konveyöre } \\
\text { verirken }\end{array}$ & $\begin{array}{l}\text { İnsan } \\
\text { Davranışı } \\
\text { Makine } \\
\text { Malzeme }\end{array}$ & 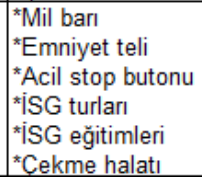 & $\mid \begin{array}{c}\text { Rutin/No } \\
\text { n-Rutin }\end{array}$ & $\begin{array}{l}\text { İşçi Sağlığı ve İş } \\
\text { Güvenliği Kanunu }\end{array}$ & 3 & 3 & 9 & 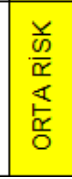 & $\begin{array}{l}\text { *Alan Tarayıcı } \\
\text { *Işık perdesi } \\
\text { *Çift kontaklı } \\
\text { digital switchler }\end{array}$ & 3 & 2 & 6 & 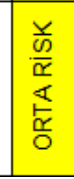 \\
\hline
\end{tabular}

\section{Sonuç}

PLC tabanlı uygulamalar endüstriyel firmalar tarafinda günümüzde hala yaygın olarak tercih edilmektedir. Özellikle kolay programlanabilir olması, zor ortam koşullarında problem yaratmadan etkin bir şekilde çalışması, kullanım ve montajının kolay yapılması, haberleşme modülleri sayesinde diğer cihazlarla iletişim kurabilmesi, arıza ve bakım maliyetinin düşük olması, enerji tüketiminin düşük olması ve kullanıcı dostu olması sebebiyle tercih edilmektedir. Makale çalışmasında, PLC tabanlı otomasyon sistemleri detaylı bir şekilde incelenmiş ve uygulandığı alanlar ele alınmıştır. Endüstriyel otomasyon sektöründe vazgeçilmez ürünler arasında yer alan PLC'ler üretimin hızlı, kaliteli, düşük maliyette ve güvenli bir şekilde yapılmasını sağlamak için kullanılmaktadır. $\mathrm{Bu}$ kapsamda, endüstriyel firmalarda kullanılan ve bazı durumlarda çalışanlar için tehlikeli olan Mill makinesinin, PLC ve HMI ile güvenli bir şekilde çalışmasını sağlayan örnek uygulama geliştirilmiştir. Yapılan bu çalışma sonucunda üretimin hızlı ve kaliteli yapılması çalışanların iş kazasına uğrama riskinin azaltılması sağlanmıştır. Geliştirilen HMI arayüz sayesinde makinalarda oluşacak arızaların ve güvenlik ekipmanlarının durumlarının kontrol ve takibi gerçekleştirilebilmektedir. Geliştirilen PLC programı ve HMI operatör ekran arayüzü sayesinde zaman, ekipman ve iş gücü maliyetleri en aza indirilmiştir. Sonuç olarak, gerçekleştirilen endüstriyel uygulamalarda kullanılan PLC ve HMI otomasyon sistemleri, çalışanların üst düzey güvenlikli ortamda çalışmasına olanak tanımaktadır.

\section{Kaynakça}

Altın, E. (2011). TIA portal ile simatic S7-1200 PLC programlama, PLC merkezi, İstanbul, www.plcmerkezi.com

Anas, A. M., Durdu, A., \& Terzioğlu, H. (2019). Kavşak Trafik Sinyalizasyon Kontrolü için Bulanık Mantık Yöntemi ile Gerçek Zamanlı Sistemin Tasarımı ve Uygulaması. Avrupa Bilim ve Teknoloji Dergisi, 490-497.

Anonim, (2020a). https://automationforum.co/working-principlelimit-switch/ Ziyaret Tarihi: 20.05.2020
Anonim,

(2020b)

https://www.sick.com/tr/tr/c/products\#g191551/ Ziyaret Tarihi: 20.05.2020

Aydoğdu, Ö., \& Çatkafa, (2019). A. bir hidrolik derin çekme pres makinesinin PLC tabanlı bulanık mantık kontrolü ve endüstri 4.0 uygulaması. Konya Mühendislik Bilimleri Dergisi, 7(3), 573-584.

Bolton, W. (2015). Programmable logic controllers. Newnes.

Çetin, R. (2004). S7-200'PLC'lerle Otomasyon, Doğusum Matbaacilık ve Tic. Ltd. Sti., Ankara, Türkiye, 11-431.

Eminoğlu Y. (2013). PLC Programlama ve S7 1200. Birsen Yayınevi, İstanbul.

Eminoğlu, Y. (2014). PLC programlama ve S7-300/400. Birsen Yayınevi, İstanbul.

Erdinç, F. (2019). Siemens S7-1200 ile PLC Programlama \& Otomasyon Deniz Ofset Matbaacılık 4.Bask1 2019 Zeytinburnu/İstanbul

Hız, O. (2019). Cisimleri renklerine göre seçen PLC kontrollü robot kol tasarımı ve uygulaması (Master's thesis, Kütahya Dumlupınar Üniversitesi/Fen Bilimleri Enstitüsü).

Kafalı, A. (2019). PLC ve SCADA tabanlı sıvı boya dozajlama sisteminin gerçekleştirilmesi ve performansının incelenmesi Yüksek Lisan Tezi, T.C. Necmettin Erbakan Üniversitesi Fen Bilimleri Enstitüsü, Konya.

Kaloyan, (2018). https://cyberx-labs.com/glossary/plcprogrammable-logic-controller/. Erişim Tarihi:15.05.2020

Karayel, M. (2013). Mikrotip hidroelektrik santraller için PLC tabanlı SCADA system otomasyonu ve RTU/PLC ile frekans ve gerilim regülasyonunun gerçekleştirilmesi, Yüksek Lisans Tezi, Gazi Üniversitesi Fen Bilimleri Enstitüsü, Ankara

Kiangala, K. S., \& Wang, Z. (2019). An Industry 4.0 approach to develop auto parameter configuration of a bottling process in a small to medium scale industry using PLC and SCADA. Procedia Manufacturing, 35, 725-730.

Kıvılcım, B. (2019). Omurilik Felçli Bireyler İçin SCADA Sistemi ve Güneş Paneli İle Desteklenmiş Akıllı Ev Model Uygulaması (Master's thesis, Fen Bilimleri Enstitüsü).

Kurtulan, S. (2008). PLC ile Endüstriyel Otomasyon, Birsen Yayınevi, İstanbul, Türkiye.

MEGEB, (2011). Elektrik- elektronik teknolojisi temel PLC sistemleri, Millî Eğitim Bakanlığı, Ankara, 5-16 
Nazım, İ. M. A. L. (2020). Su Şebeke Otomasyon Sistemi ve Uygulaması, Bilecik Şeyh Edebali Üniversitesi Fen Bilimleri Dergisi, 7(100. Y1l Özel Say1), 353-362

Nguyen, T. (2020). PLC Controlling Program of an Elevator. Bachelor's Thesis Valkeakoski, Electrical and Automation Engineering, Häme University of Applied Sciences (HAMK).

Özer, A. (2016). Endüstriyel sistemlerde plc ve scada uygulamasi,Yüksek Lisans Tezi, Marmara Üniversitesi Fen Bilimleri Enstitüsü, İstanbul.

Picorone, A. A., de Oliveira, T. R., Sampaio-Neto, R., Khosravy, M., \& Ribeiro, M. V. (2020). Channel characterization of low voltage electric power distribution networks for PLC applications based on measurement campaign. International Journal of Electrical Power \& Energy Systems, 116, 105554.

Salihoğlu, R. (2012) Açık Kaynak Kütüphane Otomasyon Sistemlerinin Akademik Kütüphanelerde Kullanımı, Yüksek Lisans Tezi, Ankara Üniversitesi, Sosyal bilimler Enstitüsü, Bilgi ve Belge Yönetimi Ana Bilim Dalı, Anakara.

Schäfer, M., Moll, P., Brocke, L., Coutandin, S., \& Fleischer, J. (2019). Model for Web-Application based Configuration of
Modular Production Plants with automated PLC Line Control Code Generation. Procedia CIRP, 83, 292-297.

Su, H., Luo, Z. A., Feng, Y. Y., \& Liu, Z. S. (2019). Application of Siemens PLC in Thermal Simulator Control System. Procedia Manufacturing, 37, 38-45.

Şengül, Ö., Öztürk, S., \& Kuncan, M. (2020). Color Based Object Separation in Conveyor Belt Using PLC. Avrupa Bilim ve Teknoloji Dergisi, 18, 401-412.

Thompson, S. (1996). Haskell: The Craft of Functional Programming https://www.cs.kent.ac.uk/people/staff/sjt/ Haskell_craft/ Ziyaret Tarihi: 20.05.2020.

Tosun, M. F., Gençkal, A. A., \& Şenol, R. (2019). Modern Kontrol Yöntemleri ile Bulanık Mantık Temelli Oda Sicaklık Kontrolü. Süleyman Demirel Üniversitesi Fen Bilimleri Enstitüsü Dergisi, 23(3), 992-999.

Waugh, A. (2020) https://library.automationdirect.com/what-is-alimit-switch/, Ziyaret Tarihi: 20.05.2020. 